\title{
DESCRIPTIONS OF DOLIUM MAGNIFICUM, N.sP., AND MUREX MULTISPINOSUS, N.SP.
}

\author{
By G. B. Sowerby, F.L.S.
}

Read 13th November, 1903.

\section{Dolium magnificum, n.sp.}

Testa subglobosa, tenuis, alba, fusco sex - balteata, flammulis interruptis brevibus irregulariter undulatis castaneis picta; spira breviter conica; anfractus 7 , primi 3 minuti, læves, deinde rapide accrescentes, convexi, irregulariter spiraliter sulcati; sutura angustissime canaliculata; anfractus ultimus per-inflatus, rotundatus, longitudinaliter striatus, hic illic leviter malleatus, sulcis spiralibus

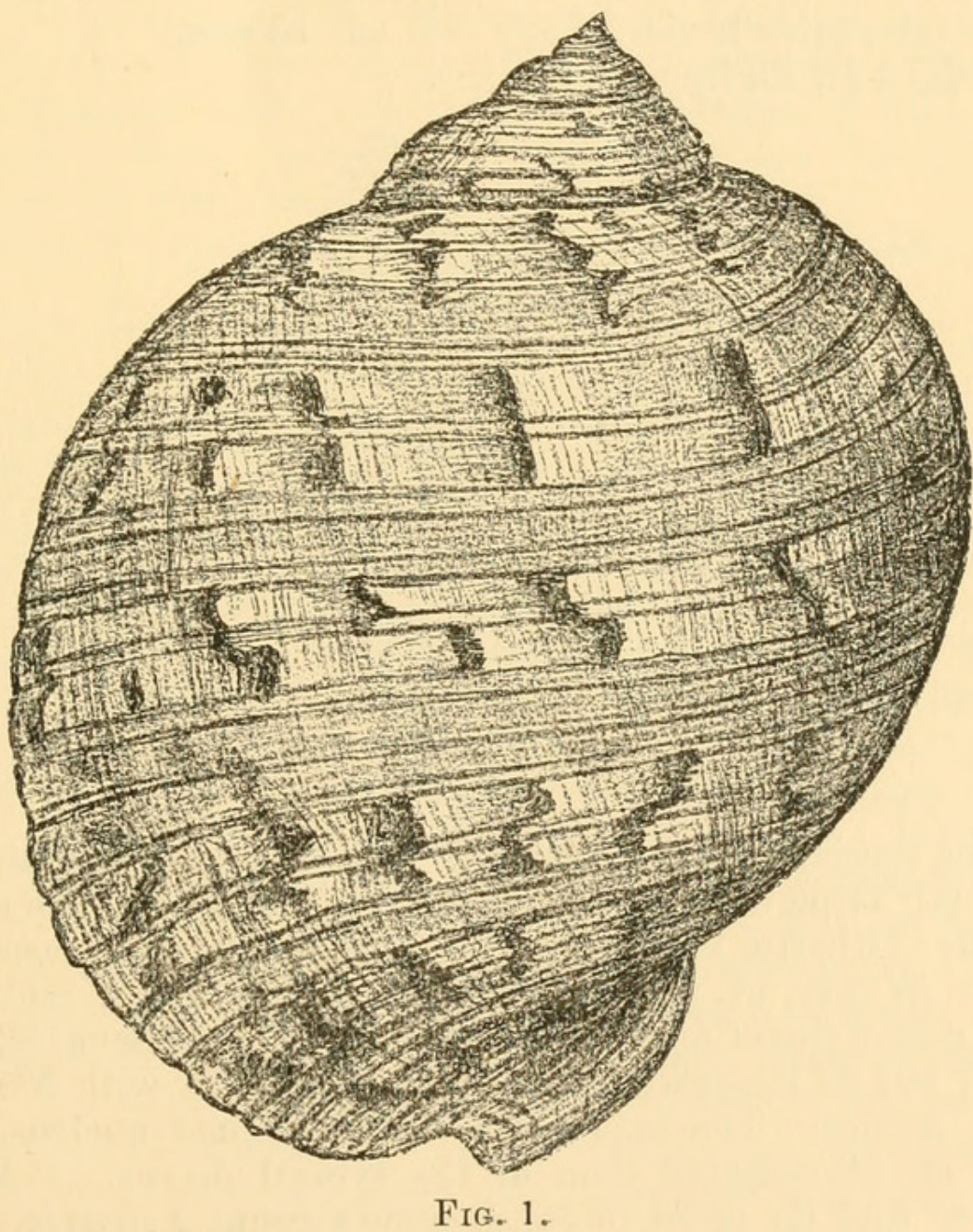

numerosis angustis plerumque duplicatis sculptus; apertura ampla, intus alba, pallide fusco tincta, duplicatim lirata. Long. 110, lat. $100 \mathrm{~mm}$.

Hab.-China Sea.

This handsome shell has some affinity with $D$. variegatum, Lamk., and D. Chinense, Dillwyn. Its colouring is characteristic. Crossing the white spaces between the brown bands are dark brown waved 
flames, which are clearly defined against the white ground on the right-hand side, and shaded off with lighter colour on the left. The narrow clean-cut grooves are for the most part arranged in pairs, the spaces between them being flat, or nearly so, not rounded as in D. Chinense and some other species.

The specimen was brought from China by the late General Tripe.

\section{Murex multispinosus, n.sp.}

Testa fusiformis, antice producta, postice conica, sordide albida; spira elato-conica, gradata, ad apicem papillaris, luteo-fusca, leviter obliqua; anfractus $6 \frac{1}{2}$, primi $1 \frac{1}{2}$ (apicales) læves, rotundati, cæteri obtuse angulati, spiraliter obscure lirati, obtuse bicarinati, longitudinaliter undulatim eximie lamellati, varicibus 9-10 aculeatim spinosis instructi; anfractus ultimus supra convexus, infra rostratus; rostrum elongatum, rectiusculum, supra spinosum, infra lævigatum; apertura ovata, intus lævis. Long. 23, lat. $13 \mathrm{~mm}$.

Hab.-Cebú I., Philippines (Tripe).
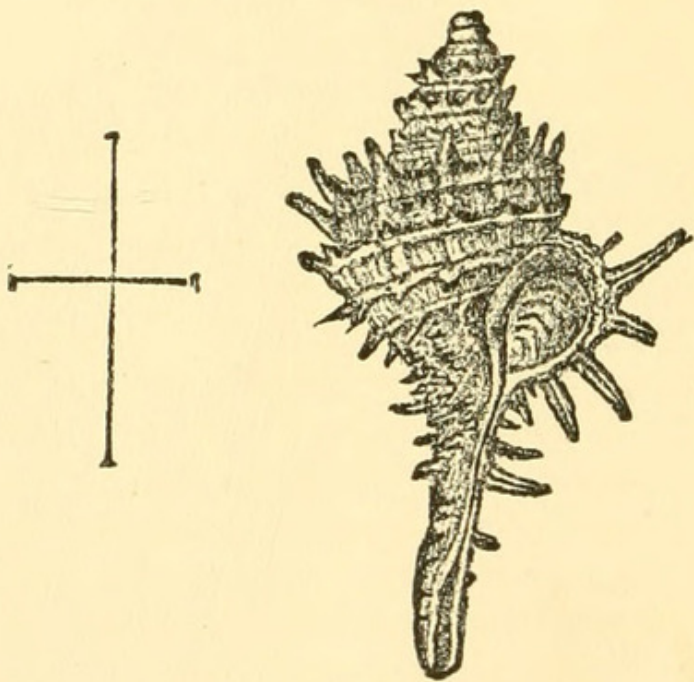

FIG. 2.

Only one specimen of this beautiful little species was found by the late General Tripe during his trip to the Far East. The shell is so unlike any hitherto known, that I am unable to place it with confidence in any of the recognised sections. As a multivaricose Murex it might (sensu lato) be included in the subgenus Muricantha, Swainson; but its long rostrum brings it into affinity with Rhinocantha, H. \& A. Adams. The operculum, with terminal nucleus, is more like that of Rhinocantha than of the typical Murex. Possibly the species may find its place in Jousseaume's genus Poirieria, of which M. Zealandicus, Quoy \& Gaim., is the type. 


\section{$2 \mathrm{BHL}$ Biodiversity Heritage Library}

Sowerby, G. B. 1904. "DESCRIPTIONS OF DOLIUM MAGNIFICUM, N.SP., AND MUREX MULTISPINOSUS, N.SP." Proceedings of the Malacological Society of London 6, 7-8.

View This Item Online: $\underline{\text { https://www.biodiversitylibrary.org/item/52315 }}$

Permalink: https://www.biodiversitylibrary.org/partpdf/202830

\section{Holding Institution}

Smithsonian Libraries

\section{Sponsored by}

Smithsonian

\section{Copyright \& Reuse}

Copyright Status: Public domain. The BHL considers that this work is no longer under copyright protection.

This document was created from content at the Biodiversity Heritage Library, the world's largest open access digital library for biodiversity literature and archives. Visit BHL at https://www.biodiversitylibrary.org. 